\title{
Arbuscular mycorrhizal status of pioneer plants from the mouth of lake Budi, Araucanía Region, Chile
}

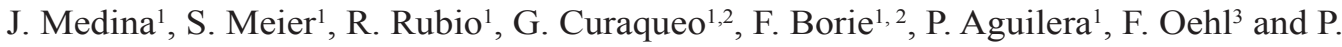 \\ Cornejo ${ }^{1,2 *}$ \\ 'Departamento de Ciencias Químicas y Recursos Naturales, Universidad de La Frontera, Temuco, Chile. \\ ${ }^{2}$ Scientific and Technological Bioresource Nucleus (BIOREN), Universidad de La Frontera, Temuco, Chile. \\ ${ }^{3}$ Agroscope, Federal Research Institute for Sustainability Sciences, Plant-Soil-Interactions, CH-8046 Zürich, \\ Switzerland. *Corresponding author: pablo.cornejo@ufrontera.cl
}

\begin{abstract}
Arbuscular mycorrhizal fungi (AMF) have an important role on the ecosystem stability promoting water and nutrient acquisition by plants and allowing their growth under stress conditions including drought and salinity. This study aimed at describing the colonization of native AMF associated to pioneer plant species growing at the mouth of lake Budi, which receive seasonally marine water. For this, root samples and rhizosphere substrate of Polygonum maritimum, Carpobrotus chilensis, Ambrosia chamissonis, Ammophyla arenaria were collected and analyzed. Mycorrhizal root colonization, spore and hyphal density, and some soil chemical properties (pH, conductivity, organic matter -OM-, and microbial activity) were determined. Results showed that A. Arenaria presented the highest root colonization (53\%), mycelium $\left(10 \mathrm{~m} \mathrm{~g}^{-1}\right)$ and AMF spores (300 spores in $100 \mathrm{~g}$ of substrate) densities, which were highly correlated with an elevated OM content $(1.64 \% ; \mathrm{r}=0.53, \mathrm{r}=0.48$ y r $=0.87$, respectively) and soil microbial activity ( $3.57 \mu$ g fluorescein $\mathrm{g}^{-1} \mathrm{~h}^{-1} ; \mathrm{r}=0.89 \mathrm{r}=0.76$ and $\mathrm{r}=0.53$, respectively). On the other hand, a low AMF species richness was found in the rhizospheric soils of all four evaluated plants, finding a total of five AMF species. Nevertheless, one of these corresponds to a new specie (Corymbilomus pacificum), which was associated to A. arenaria. Our results suggest an important role of AMF associated to pioneer plants in saline ecosystems, especially enhancing the establishment of A. arenaria and Amb. chamissonis, which could promote a further nurse effect that allow the establishment of other plant species. AM fungi could be considered as a biotechnological tool since they could be used for stabilization of coastal ecosystems, and in soils under saline or hydric limitations.
\end{abstract}

Keywords: Rhizosphere microorganisms, nutrients, AMF communities, salinity 


\section{Introduction}

Arbuscular mycorrhizal fungi (AMF, phylum Glomeromycota) are essential microorganisms involved in ecosystem stability and functioning due to their important role enhancing water and nutrient acquisition and promoting the tolerance to different biotic and abiotic stresses (Schüßler et al., 2001; van der Haudens and Sanders, 2002; Oehl and Sieverding, 2004; Caporale et al., 2014). In this sense, it has been noticed that AMF may improve the tolerance to dry stress and phytopatogens (Hooker et al.,1994; Banuelos et al., 2014) produced by high salinity in coastal ecosystems. On the other hand, AMF are able to affect the composition and structure of vegetal community (vander Heijdenand Vosatka 1999), and plants growth (Streitwolf-Engel et al., 1997). There are different levels of functional compatibility in the arbuscular mycorrhizal (AM) symbiosis, having an important effect over the floristic composition in the different types of ecosystems and being determinant for the structure of plant community as consequence of diverse dependence degrees between plant species and AMF (Sánchez, 2009).

In coastal ecosystems AMF promote aggregation of sand particles, controlling the wind erosion and increasing the water holding capacity of substrate (Sylvia and Will, 1988). AMF have a direct effect in the nutrient uptake of plants enhancing the interaction between physicalchemical matrix of substrate and biotic component from ecosystem (Gonzales et al., 1995). Some previous studies about plant growth and establishment of pioneer species suggested a high dependence for AMF, which enhance the water and nutrients acquisition from poor substrates in coastal ecosystems (Gonzales et al., 1995). Therefore, the plant community composition and the succession of plants strongly depend on mycorrhizal status of plants in those environments (Nicolson and Johnston, 1979; Gonzales et al., 1995; Gomes da Souza et al., 2010).

Lake Budi is an unusual coastal lake in La Araucanía Region (Southern Chile). When the lake water levels rise after high winter rainfalls or during exceptionally high tides, the lake connects with the Pacific Ocean, while it is rarely connected during the summers (Peña-Cortés et al., 2006). During high tides, ocean water enters to the lake, giving it a brackish nature (1.5-2.0\% salt; Basualto et al., 2006). In this lakeshore, plant species corresponding to halophytes and macrophytes are adapted to different types of biotic and abiotic stresses including salinity, drought and low levels of nutrients (Hauenstein, 2005).

In Chile, Gonzales et al. (1995) noticed the presence of AMF associated to A. arenaria. However, studies that describe and highlight the presence and possible effects of AMF in the growth, establishment and tolerance of these types of plants in the particular lakeshore above described have not yet been carried out. Therefore, the objective of this study was to describe the presence of AMF associated to the rhizosphere of pioneer plants from mouth of lake Budi, and to determine their relation with some soil parameters which could explain the establishment of these plants under stress conditions.

\section{Materials and Methods}

\subsection{Study site}

Lake Budi (approximately $56 \mathrm{~km}^{2}$ ) is located on the Pacific coastline of the municipality of Puerto Saavedra in La Araucanía Region (Southern Chile, 
$\left.38^{\circ} 53^{\prime} \mathrm{S} 73^{\circ} 17^{\prime} \mathrm{W}\right)$. It is typical Pacific seaside climate described as Mediterranean or Temperate Oceanic, which has a narrow temperature range (annual average temperature of $12{ }^{\circ} \mathrm{C}$ ) due to the marine and lacustrine thermoregulation effect (Peña-Cortés et al., 2006); summer maximum and minimum temperatures average $18-20^{\circ} \mathrm{C}$ and $9-11^{\circ} \mathrm{C}$, while winter averages are $13-14{ }^{\circ} \mathrm{C}$ and $0.5-7{ }^{\circ} \mathrm{C}$. The annual average rainfall, concentrated between autumn (March) and early spring (August), is $1350 \mathrm{~mm}$ (Peña-Cortés et al., 2006; 2008). Fragmentation of ecosystem has been described for lake Budi (Hauenstein et al., 2005) due to the development of different human activities as agriculture which contributes to this process.

\subsection{Plants and substrate sampling}

Several pioneer species Ammophila arenaria (Poaceae), Ambrosia chamissonis (Less.) Greene (Asteraceae), Polygonum maritimum L. (Polygonaceae), and Carpobrotus chilensis (Molina) N.E. Br. (Aizoaceae) were obtained from the lake-ocean transition zone $\left(38^{\circ} 49^{\prime} 34^{\prime \prime} \mathrm{S} 73^{\circ} 23{ }^{\circ} 43^{\prime \prime} \mathrm{W}\right)$ characterized for bidirectional water flux from sea. Four plants of each species were sampled from several plots $\left(100 \mathrm{~m}^{2}\right)$ as described by Brawn-Blanquet and Jenny (1926). Substrate samples were obtained from rhizosphere zone of each sampled plant, stored in bags and dried at room temperature for $48 \mathrm{~h}$ before analysis. Roots from plants were stored under cooled conditions. Additionally, samples of bare substrate were taken and characterized (Table 1).

Table 1. General characteristics of the bare substrate obtained from the mouth of lake Budi, Puerto Saavedra, Chile.

\begin{tabular}{|l|c|}
\hline $\mathrm{N}\left(\mathrm{mg} \mathrm{kg}^{-1}\right)^{*}$ & Not detected \\
\hline $\mathrm{P}\left(\mathrm{mg} \mathrm{kg}^{-1}\right)$ & 4 \\
\hline $\mathrm{pH}$ & 7.49 \\
\hline Orgater & Not detected \\
\hline $\mathrm{K}\left(\mathrm{cmol}(+) \mathrm{kg}^{-1}\right)$ & 0.19 \\
\hline $\mathrm{Na}\left(\mathrm{cmol}(+) \mathrm{kg}^{-1}\right)$ & 0.19 \\
\hline $\mathrm{Ca}\left(\mathrm{cmol}(+) \mathrm{kg}^{-1}\right)$ & 2.0 \\
\hline $\mathrm{Mg}\left(\mathrm{cmol}(+) \mathrm{kg}^{-1}\right)$ & 0.74 \\
\hline $\mathrm{Al}\left(\mathrm{cmol}(+) \mathrm{kg}^{-1}\right)$ & 0.01 \\
\hline $\mathrm{Al} \mathrm{saturation}(\%)$ & 0.32 \\
\hline $\mathrm{CEC}\left(\mathrm{cmol}(+) \mathrm{kg}^{-1}\right)$ & 3.13 \\
\hline Sum of Basis $\left(\mathrm{cmol}(+) \mathrm{kg}^{-1}\right)$ & 3.12 \\
\hline
\end{tabular}

* N, Kjeldahl method; available $\mathrm{P}$ by Olsen method; exchangeable $\mathrm{Ca}, \mathrm{Mg}, \mathrm{Na}$ and $\mathrm{K}$ : extraction by $\mathrm{CH}_{3} \mathrm{COONH}_{4} 1 \mathrm{M} \mathrm{pH}$ 7.0; exchangeable $\mathrm{Al}$ : extraction with $\mathrm{KCl} 1 \mathrm{M}$; $\mathrm{CICE}=\mathrm{Ca}, \mathrm{Mg}, \mathrm{K}, \mathrm{Na}$ and $\mathrm{Al}$ exchangeable; $\mathrm{Al}$ saturation: exchangeable $\mathrm{Al} \mathrm{x}$ 100/CICE. Analytics techniques under CNA rules, Chilean Society of Soil Science 


\subsection{Substrate analysis}

Some chemicals properties as $\mathrm{pH}$ and conductivity were carried out. $\mathrm{pH}$ was determined by potentiometry of the mixed substrate and water or $\mathrm{CaCl}_{2}$ solution (2:5 $\mathrm{w} / \mathrm{w})$. Conductivity was evaluated in the extract of the mixed substrate with deionized water $\left(<0.1 \mathrm{mS} \mathrm{cm}^{-1}\right)$ at $1: 5 \mathrm{w} / \mathrm{v}$ relation. Organic matter of substrate was determined by Walkley and Black (1934) method and was stated as \% respect to dry substrate. Microbial activity was measured by fluorescein diacetate hydrolysis according to Alvear et al. (2007) and was expressed as $\mu \mathrm{g}$ fluorescein $\mathrm{g}^{-1} \mathrm{~h}^{-1}$.

\subsection{AM fungal analysis}

Arbuscular rmycorrhizal root colonization was quantified using a dissection microscope (20-40X) after clearing a portion of roots in $10 \% \mathrm{KOH}(\mathrm{w} / \mathrm{v})$ and staining in $0.05 \%$ trypan blue in lactic acid (w/v). The gridline intersection method (Giovannetti and Mosse, 1980) was used to determine the proportion of root colonized by AMF. The spores were separated from soil by wet sieving and decanting in a $70 \%(\mathrm{w} / \mathrm{v})$ sucrose solution (Gerdemann and Nicolson, 1963) and quantified using a dissecting microscope. Additionally, some spores were stored and analyzed for morphology and subcellular structures based on observations of specimens mounted in polyvinyl alcohol-lactic acidglycerol (PVLG; Koske and Tessier, 1983), a mixture of PVLG and Melzer's reagent (Brundrett et al., 1994), a mixture of lactic acid and water at 1:1, Melzer's reagent, and water (Spain 1990). The total extraradical mycorrhizal hyphae were determined by the method described in Borie et al. (2000). To quantify the total hyphal density, we used Newman`s intersect gridline method (1966).

\subsection{Statistical analyses}

For all the studied variables, one-way ANOVA was performed. Data sets not meeting assumptions for ANOVA (normality, homocedasticity) were transformed as required, but the results are presented in their original scale of measurement. Means were compared byTukey's multiple range test. All the data sets were subjected to correlation (R coefficient) and factorial analysis with Principal Components (PC) extraction followed for a Cluster analysis using Ward's method. Statistical significance was determined at $P<0.05$. Statistical analyses were performed with the SPSS software v. 10.0 (SPSS, Inc. Chicago, Il.)

Table 2. Chemical and biochemical characteristics of the growth substrate of four plant species in the mouth of lake Budi, Araucanía Region $(n=4)$.

\begin{tabular}{|l|c|c|c|c|}
\hline Plant specie & $\mathrm{pH}\left(\mathrm{CaCl}_{2}\right)$ & $\begin{array}{c}\text { Electrical } \\
\text { Conductivity } \\
(\mathrm{dS} \mathrm{m})^{-1}\end{array}$ & $\begin{array}{c}\text { Organic matter } \\
(\%)\end{array}$ & $\begin{array}{c}\text { Fluorescein diacetate activity } \\
\left(\mu \mathrm{FDA} \mathrm{g}^{-1} \mathrm{~h}^{-1}\right)\end{array}$ \\
\hline Polygonum maritimum & $6.28 \mathrm{a}$ & $4.9 \mathrm{a}$ & $0.56 \mathrm{~b}$ & $1.06 \mathrm{~b}$ \\
\hline Carpobrotus chilensis & $6.29 \mathrm{a}$ & $2.4 \mathrm{c}$ & $0.45 \mathrm{~b}$ & $0.65 \mathrm{~b}$ \\
\hline Ambrosia chamissonis & $6.24 \mathrm{~b}$ & $4.3 \mathrm{~d}$ & $0.67 \mathrm{~b}$ & $3.48 \mathrm{a}$ \\
\hline Ammophila arenaria & $6.11 \mathrm{~b}$ & $3.5 \mathrm{~b}$ & $2.20 \mathrm{a}$ & $3.57 \mathrm{a}$ \\
\hline F-value & $8.61^{*}$ & $217^{* *}$ & $10.8^{*}$ & $39.9^{* *}$ \\
\hline
\end{tabular}

$* P<0.05 ; * * P<0.001$ 


\section{Results}

\subsection{Characterization of soil samples}

The results showed homogeneous ph values in all the analyzed rhizosphere samples (6.1-6.3, Table 2). In this regard, A. arenaria showed low $\mathrm{pH}$ values together with high OM accumulation (reaching 2.2\% in A. arenaria). High levels of electrical conductivity were found in all substrates analyzed (with values of $\sim 4.9 \mathrm{dS} \mathrm{m} \mathrm{m}^{-1}$ ) which were independent of the rhizosphere analyzed. Hydrolysis of the FDA, used as an indicator of the biochemical activity of the microbiota, showed high activity in the rhizosphere of $A$. arenaria substrate as well in Amb. chamissonis, with values of 3.5-3.6 $\mu \mathrm{g}$ fluorescein $\mathrm{g}^{-1} \mathrm{~h}^{-1}$.

\subsection{AM fungal characteristics}

The four plants species analyzed presented mycorrhizal colonization in their roots, reaching the highest values in Amb. chamissonis and $A$. arenaria, whereas the other two species showed low root colonization percentages (Table 3). Meanwhile, the extraradical fungal mycelium presented the same trend observed in the case of root colonization, highlighting A arenaria, with densities of $10.6 \mathrm{~m} \mathrm{~g}^{-1}$, which were higher than in the rhizospheres of the other three plants analyzed. Nevertheless, the spore density was 9-15 fold higher in A. arenaria, compared to the other plants.

Spores of AMF extracted from different rhizosphere soils showed low species richness, being dominated by only 5 species, which were identified through observations of their morphological characteristics: Septoglomus constrictum, Acaulospora srobiculata, Glomus macrocarpum, Claroideoglomus claroideum, and Corymbiglomus pacificum which was recently described from lake Budi (Medina et al., 2014).

Table 3. Mycorrhizal colonization and propagule densities in roots and growth substrate of four plant species in the mouth of lake Budi, Araucanía Region ( $n=4)$.

\begin{tabular}{|l|c|c|c|}
\hline Plant species & Colonization (\%) & Mycelium $\mathbf{( \mathbf { m ~ g } ^ { - 1 } )}$ & $\begin{array}{c}\text { Spore density } \\
\left(\mathbf{1 0 0 \mathbf { g } ^ { - 1 }}\right)\end{array}$ \\
\hline Polygonum maritimum & $29.3 \mathrm{~b}$ & $6.0 \mathrm{bc}$ & $33 \mathrm{~b}$ \\
\hline Carpobrotus chilensis & $28.6 \mathrm{~b}$ & $3.5 \mathrm{c}$ & $30 \mathrm{~b}$ \\
\hline Ambrosia chamissonis & $49.5 \mathrm{a}$ & $8.6 \mathrm{ab}$ & $20 \mathrm{~b}$ \\
\hline Ammophila arenaria & $54.7 \mathrm{a}$ & $10.6 \mathrm{a}$ & $298 \mathrm{a}$ \\
\hline F-value & $32.4^{* *}$ & $9.02 *$ & $114^{* *}$ \\
\hline
\end{tabular}

$* P<0.05 ; * * P<0.001$

\subsection{Relations between substrate characteristics and AM fungal characteristics}

Bivariate correlation analysis showed the presence of numerous significant relationships in all parameters evaluated (Table 4), highlighting those among the $\mathrm{OM}$ of the substrate, the FDA rhizosphere activity and the spore density in the soil. The PC1 was significantly associated with all variables, except for $\mathrm{pH}$ and $\mathrm{EC}$, where in the first case the correlation was 
negative and in the second there were no association with this variable. Meanwhile, the conductivity was significantly related to the PC2 (Table 4). Overall, the factorial analysis showed a high association among the variables related to the densities of mycorrhizal propagules with the OM contents and FDA activity, while conductivity and $\mathrm{pH}$ were not related either among them or with any other variable (Figure. 1A). The above analysis also showed that the first two components explain more than $81 \%$ of the experimental variance. Additionally, the cluster analysis showed high homogeneity in the variables for each type of plant species, forming A. arenaria a well-defined conglomerate. The same behavior was observed for Amb. chamissonis. Finally, P. maritimum and $C$. chilensis form a more heterogeneous but clearly separate group in comparison of the previously mentioned (Figure 1B).

Table 4. Bivariate correlations ( $\mathrm{R}$ Pearson) between the analyzed variables and the principal components $(\mathrm{CP})$ obtained $(\mathrm{N}=16)$.

\begin{tabular}{|l|c|c|c|c|c|c|c|c|}
\hline Variables & $\mathbf{2}$ & $\mathbf{3}$ & $\mathbf{4}$ & $\mathbf{5}$ & $\mathbf{6}$ & $\mathbf{7}$ & PC1 & PC2 \\
\hline$p H(1)$ & 0.27 & $-0.78^{* *}$ & -0.39 & $-0.68^{* *}$ & $-0.64^{* *}$ & -0.5 & $-0.80^{* *}$ & 0.37 \\
\hline Conductivity (2) & & -0.18 & -0.28 & -0.15 & 0.13 & 0.33 & 0.00 & $0.89^{* *}$ \\
\hline FDA (3) & & & 0.43 & $0.89^{* *}$ & $0.76^{* *}$ & $0.53^{*}$ & $0.89^{* *}$ & -0.31 \\
\hline Organic matter (4) & & & & $0.53^{*}$ & 0.48 & $0.87^{* *}$ & $0.73^{* *}$ & 0.50 \\
\hline Colonization (5) & & & & & $0.73^{* *}$ & $0.59^{*}$ & $0.90^{* *}$ & -0.21 \\
\hline Mycelium (6) & & & & & & $0.56^{*}$ & $0.85^{* *}$ & 0.00 \\
\hline Spores (7) & & & & & & & $0.80^{* *}$ & 0.47 \\
\hline
\end{tabular}

$* P<0.05 ; * * P<0.001$

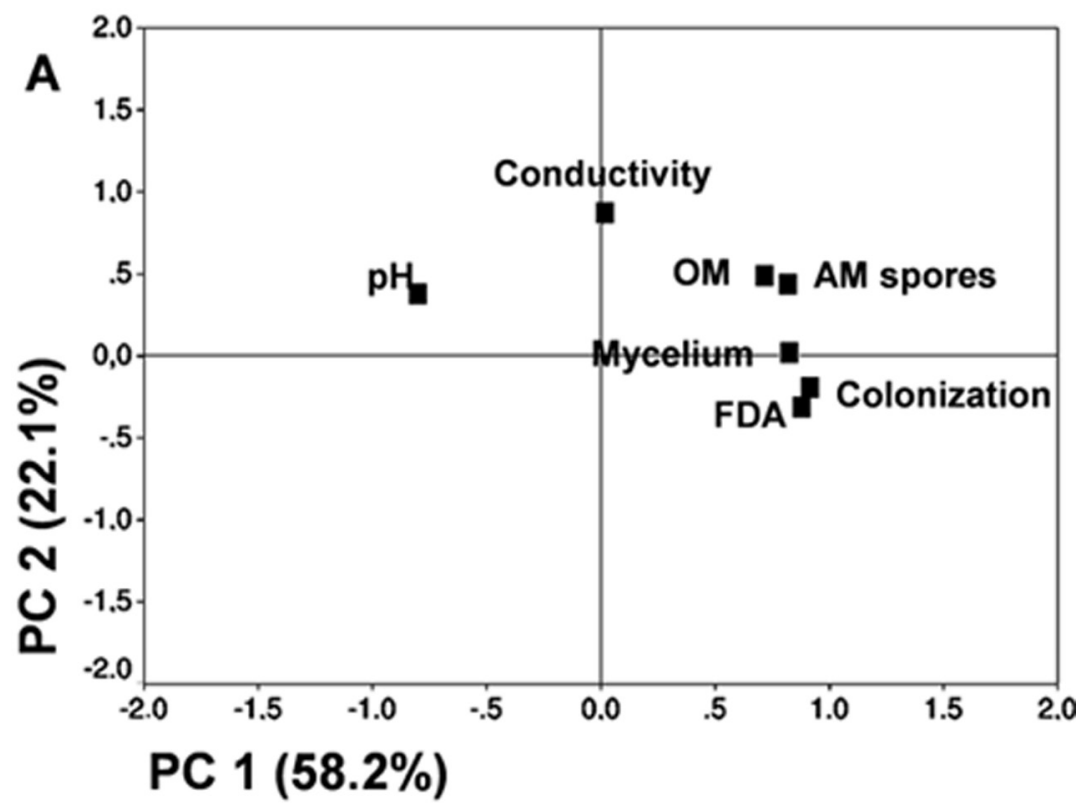




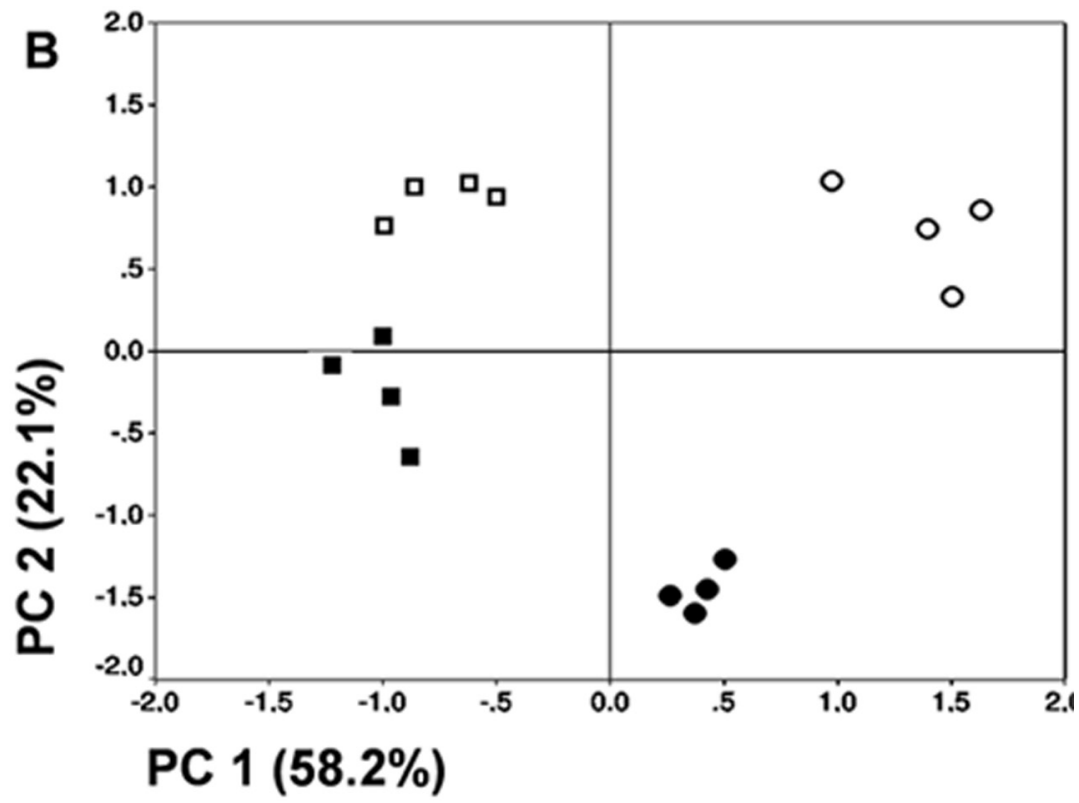

Figure 1. Principal component analysis for studied parameters (A) and experimental units (B) in rizhospheric substrate and

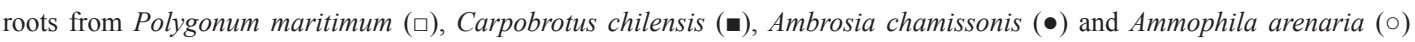
obtained from Budi lakeshore, Araucanía Region. Abbreviations: fluorescein diacetate activity (FDA), organic matter (OM), arbuscular mycorrhizal (AM).

\section{Discussion}

In coastal ecosystems pioneer plant species that colonize sites need some individual tolerance mechanisms (Gonzales et al., 1995). In this sense, the symbiosis between AMF and vascular plants is a common and important strategy to overcome the diverse limitations for plant establishment in this kind of ecosystems (Godoy and Gonzales, 1994). As observed in the initial characterization of the substrate (Table 1), nutritional conditions showed low $\mathrm{P}$ and $\mathrm{N}$ contents, probably being the mycorrhizal associations the main way for nutrient absorption, thereby the mycorrhizal plants could be involved in the generation of "resource islands", where new mycorrhized plant individuals are able to colonize the ecosystem in a next step (Gonzales et al., 1995). Ammophila arenaria develops a long root system which may be colonized by AMF (Giovannetti and Nicolson, 1983; Giovannetti et al., 1985; Kowalchuk et al., 2002; Maremmani et al., 2003; Rodríguez-Echevarría et al., 2008). Previous studies have shown that a number of AM fungal species belonging to several genera (e.g., Acaulospora, Diversispora, Funneliformis, Glomus, Racocetra, and Scutellospora) are associated with $A$. arenaria (Błaszkowski, 1994; Kowalchuk et al., 2002; Rodríguez-Echeverría and Freitas, 2006; Estrada et al., 2011).

The results presented in this study are in agreement with other studies of AMF colonization in vascular plants from coastal areas, showing in most of the cases a high dependence of the symbiosis for the 
establishment, colonization, growth and subsequent dissemination. In this study it was observed that all plant species developed AM colonization, including one with no previous information (C. chilensis), or belonging to rather non-mycorrhizal botanical families (P. maritimum, Polygonaceae). These results would indicate a high dependence of this kind of symbiosis by plants present in this ecosystem, which would become dependent of mutualistic associations to tolerate the environmental constraints, particularly the lack of nutrients. In this regard, under other conditions of abiotic stress, such as that generated by metal contamination, similar results were obtained: such as the presence of plants with high AMF colonization rates in response to elevated levels of contamination, or even the AM colonization in species described as non-mycorrhizal species (Meier et al., 2012).

The AMF progagules found due to the presence of highly colonized plants (A. arenaria and Amb. chamisonis) could facilitate the colonization processes for other plants, which are less able to be colonized. Among these, highlighted A. arenaria, whose levels of root colonization, spore and mycelium densities were notoriously higher. These results are also related to the FDA activity and OM content, demonstrating the role of $A$. arenaria and its associated AMF as island of resources. Previously, A. arenaria has been highlighted in other ecosystems as a leading pioneer plant of coastal ecosystems, since its establishment in coastal areas allows the subsequent establishment of other plant species due to its ability to accumulate sediment and nutrients that can be used by other plants (Huiskes 1979; De Rooij-van der Goes et al., 1997). However, its role as a source of mycorrhizal inoculum has been little studied. Based on our results, Amb. chamissonis appears to be highly dependent of AMF. However, the number of propagules, especially resistance spores, was significantly lesser compared to $A$. arenaria, so its role promoting the colonization of new individuals of the same or other plant species might be less important due to a minor inoculum potential.

Some diversity studies have previously described a number of AMF species associated with coastal ecosystems highlighting some species which are able to generate spores of a big size such as the genera Gigaspora, Scutellospora, Glomus and Pacispora (Estrada et al., 2011). In comparison, the species identified in our study are similar to those described for other coastal ecosystems, highlighting among them a newly created genus, Corymbiglomus. In fact, the AM fungal species Corymbiglomus pacificum corresponds to the first AM fungus species of coastal ecosystems described in Chile (Medina et al., 2014), and forms an important proportion of the AMF communities in the rhizosphere of A. arenaria in this study. Reinforcing, A. arenariais the dominant pioneer plant species growing on the alluvial-stony lakeshore at the mouth of lake Budi which has high sand burial tolerance and promotes dune formation through sand accumulation (Huiskes 1979; De Rooij-van der Goes et al., 1997). Also, Amb.chamissonis has been described as a promoter of coastal dune formation in Chile (San Martin et al., 1992).

The latter two aspects may be important, due to the characterization of the AMF communities, and its reproduction could allow its use in biotechnological programs in coastal dunes and ecological recovery through the establishment of plant species recognized as promoter of dune formation, especially when the AMF species better adapted to the limiting conditions of coastal ecosystems are used.

\section{Conclusions}

Pioneer plants from coastal ecosystems need to have different mechanisms to tolerate restricted 
conditions in this type of habitats. Our results suggest an important role and interaction between AMF and pioneer plants, which may enhance colonization of the lakeshore by A. arenaria and Amb. chamissonis promoting the establishment of other plants through a nurse effect of $A$. arenaria. Population of native AMF associated to plants from the studied lakeshore could be a novel biotechnological tool for plants growing in coastal ecosystems or even for plants growing under limiting conditions as drought and salinity.

\section{Acknowledgements}

P. Cornejo thanks the program FONDECYTCONICYT (1120890) for the financial support for the visit of Dr. F. Oehl. This study was partially financed by DIUFRO, Universidad de La Frontera (Chile). The authors also would like to thank Mrs. Susana García for technical support.

\section{References}

Alvear, M.,Reyes, F.,Morales, A.,Arriagada, C., Reyes, M. 2007. Actividad biológica y agregados estables al agua en dos tipos de formaciones vegetales de un bosque templado del Centro-Sur de Chile con perturbación antrópica. Ecología Austral. 17, 113-122.

Basualto, S., Tapia, J., Cruces, F., Bertran, C., Schlatter, R., Peña-cortés, F., Hauenstein, E. 2006.The effect of physical and chemical parameters on the structure and composition of the phytoplankton community of Lake Budi (IX Region, Chile). Journal Chilean Chemistry Society. 51(3): 993-999.

Banuelos, J., Alarcón, A., Larsen, J., Cruz-Sanchéz, S., Trejo, D. 2014. Interactions between arbuscular mycorrhizal fungi and Meloidogyne incognita in the ornamental plants Impatiens balsamina.
Journal of Soil Science and Plant Nutrition. 14 (1): 63-74.

Błaszkowski, J. 1994. Arbuscular fungi and mycorrhizae (Glomales) of the Hel Peninsula, Poland. Mycorrhiza. 5, 71-88.

Borie, F., Rubio, R., Morales, A., Castillo, C. 2000. Relationships between arbuscular mycorrhizal hyphal density and glomalin production with physical and chemical characteristics of soil under no-tillage. Revista Chilena de Historia Natural. 73, 749-756.

Brawn-Blanquet, J., Jenny, H. 1926. Vegetations Entwicklung und Bodenbildung in der alpine Stufe der Zentralalpen. Denkschriften der schweizerischen naturforschenden Gesellschaft. 63, 183-344.

Brundrett, M., Melville, L., Peterson, L. 1994. Practical methods in mycorrhizal research. Mycologue Publications, University of Guelph, Guelph, Ontario, Canada.

Caporale, A.G., Sarkar, D., Datta, R., Punamiya, P., Violante, A. 2014. Effect of arbuscular mycorrhizal fungi (Glomus spp.) on growth and arsenic uptake of vetiver grass (Chrysopogon zizanoides L.) from contaminated soil and water system. Journal of Soil Science and Plant Nutrition. 14 (4): 955-972.

De Rooij-van der Goes, P.E.C.M., Van dijk, C., Van der Putten, W.H., Jungerius, P.D. 1997. Effects of sand movement by wind on nematodes and soil borne fungi in coastal foredunes. Journal of Coastal Conservation, 3, 133-142.

Estrada, B., Palenzuela, J., Barea, J.M., RuízLozano, J.M., Alves da Silva, G., Oehl, F. 2011. Diversispora clara a new species from saline dunes in the Natural Park Cabo de Gata. Mycotaxon. 118, 73 - 81. 
Gerdemann, J.W., Nicolson,T.H. 1963. Spores of mycorrhizal Endogone species extractive from soil by wet sieving and decanting. Transactions of the British Mycological Society. 46, 235-244.

Giovannetti, M., Mosse, B. 1980. An evaluation of techniques for measuring vesicular arbuscularmycorrhizal infection in roots. New Phytologist. 84, 489-500.

Giovannetti, M., Nicolson, T.H.1983.Vesiculararbuscular mycorrhizas in Italian sand dunes. Transaction of British Mycology Society. 80, 552-557.

Giovannetti, M. 1985. Seasonal variation of vesiculararbuscular mycorrhizas and endogonaceous spores in a maritime sand dune, Transaction of British Mycology Society. 84, 679-684.

Godoy, R., Gonzales, B. 1994. Simbiosis micorrícica en la flora de ecosistemas dunarios del Centro-Sur de Chile. Gayana Botánica. 51, 69-80

Gomes da Souza, R., Tomo Goto, B., Karla Alves da Silva, D., Barbosa da Silva, F., Sampaio E.V.S.B., Costa Maia, L.2010. The role of arbuscular mycorrhizal fungi and cattle manure in the establishment of Tocoyena selloana Schum. in mined dune area. European Journal of Soil Biology. 46, 237-241.

Gonzales, B., Godoy, R., Figueroa, S. 1995. Dinámica estacional de Hongos micorrícicos vesículo arbusculares en ecosistemas dunarios del CentroSur de Chile. Agricultura Técnica. 55, 267-272.

Hauenstein, E., González, M., Peña-cortés, F., Muñoz-Pedreros, A. 2005. Diversidad vegetal en humedales costeros de la Región de La Araucanía. En: C, Smith-Ramírez., JJ, Armesto., C, Valdovinos (eds.). Historia, biodiversidad y ecología de los bosques costeros de Chile. Editorial Universitaria, Santiago, Chile. 197-205.
Hooker, J.E., Jaime-Vega, M., Atkinson, D. 1994. Biocontrol of plant pathogens using arbuscular mycorrhizal fungi. In: Gianinazzi S, Schuepp $\mathrm{H}$, eds, Impact of Arbuscular Mycorrhizas on Sustainable Agriculture and Natural Eco-systems. Basel, Switzerland: BirkhaĖuser-Verlag, 191-200.

Huiskes, A.H.L. 1979. Biological flora of the british isles: Ammophila arenaria (L.) Link (Psamma arenaria (L.) Roem et Schult.: Calamagrostis arenaria (L.) Roth). Journal Ecology. 67, 363382.

Koske, R.E., Tessier, B. 1983. A convenient, permanent slide mounting medium. Newsletter of America Mycology Society. 34, 59.

Kowalchuk, G.A., De Souza, F.A., Van veen, J.A. 2002. Community analysis of arbuscular mycorrhizal fungi associated with Ammophila arenaria in Dutch coastal sand dunes. Molecular Ecology. 11, 571-581.

Maremmani, A., Bedini, S., Matosevic, I., Tomei, P.E., Giovannetti, M. 2003.Type of mycorrhizal associations in two coastal nature reserves of the Mediterranean basin. Mycorrhiza. 13, 33-40.

Medina, J., Cornejo, P., Borie, F., Meier, S., Palenzuela, J., Evangelista Vieira, H.E, Costa Maia, L., Alves Da Silva, G., Sánchez-Castro, I., Oehl, F. 2014. Corymbiglomus pacificum, a new fungus in the Glomeromycetes from an unique saline lakeside in Chile. Mycotaxon. 127, 173-183.

Meier, S., Borie, F., Curaqueo, G., Bolan, N., Cornejo, P. 2012. Effects of arbuscular mycorrhizal inoculation on metallophyte and agricultural plants growing at increasing copper level. Applied Soil Ecology. 61, 280-287.

Newman, E.I. 1966. A method of stimating the total length of root in sample. Journal of Applied Ecology. 3, 139-145. 
Nicolson, T., Johnston, C. 1979. Mycorrhiza in the gramineae III. Glomus fasciculatum as the endophyte in pioneer grasses in maritime sand dunes. Transaction of the British Mycology Society. 72, 261-268.

Oehl, F., Sieverding, E. 2004. Pacispora, a new vesicular-arbuscular mycorrhizal fungal genus in the Glomeromycetes. Journal of Applied Botany and Food Quality. 78, 72-82.

Peña - Cortés, F., Rebolledo, G., Hermosilla, K., Hauenstein, E., Bertrán, C., Schlatter, R., Tapia, J. 2006. Dinámica del paisaje para el período 19802004 en la cuenca costera del lago Budi, Chile. Consideraciones para la conservación de sus humedales. Ecología Austral. 16,183-196.

Peña-Cortés, F., Ailio, C., Gutiérrez, P., EscalonaUlloa, M., Rebolledo, G., Pincheira-Ulbrich, J., Rozas, D., Hauenstein, E. 2008. Morfología y dinámica dunaria en el borde costero de la Región de La Araucanía en Chile. Antecedentes para la conservación y gestión territorial. Revista de Geografía Norte Grande. 41, 63-80.

Rodríguez-Echeverría, S., Hol, G., Freitas, W.H., Eason, H.W., Cook, R. 2008. Arbuscular mycorrhizal fungi of Ammophila arenaria (L.) Link: Spore abundance and root colonisation in six locations of the European coast. European Journal of Soil Biology. 44, 30-36.

Sánchez, I. 2009. Análisis de la estructura y diversidad de las comunidades de hongos formadores de micorrizas arbusculares asociados a plantas de especial interés ecológico en ambientes mediterráneo. Universidad de Granada, España.195 pp.
San Martín, J., Ramírez, C., San Martín, C. 1992. La flora de las dunas de Chile y sus adaptaciones morfológicas. Bosque. 13 (1): 29-39.

Schübler, A., Schwarzott, D., Walker, .C. 2001. A new fungal phylum, the Glomeromycota: phylogeny and evolution. Mycological Research. 105, 14131421.

Spain, J.L. 1990. Arguments for diagnoses based on unaltered wall structures. Mycotaxon. 38, 71-76.

Streitwolf-Engel, R., Boller, T., Wiemken, A., Sanders, I.R.1997. Clonal growth traits of two Prunella species are determined by co-occurring arbuscular mycorrhizal fungi from a calcareous grassland. Journal of Ecology. 85, 181-191.

Sylvia, D.M., Will, M.E. 1988. Establishment of vesicular - arbuscular mycorrhizal fungi and other micro-organisms on a beach replenishment site in Florida. Applied and Environmental Microbiology. 54, 348-352.

Van der Haudens, M.G.A., Sanders, I.R. 2002. Mycorrhizal ecology, Ecological Studies Vol. 7. Springer Verlag, Berlin Heiderberg, Germany.

Van der Heijden, E.W., Vosatka, M. 1999.Mycorrhizal associations of Salix repens L. communities in succession of dune ecosystems. II. Mycorrhizal dynamics and interactions of ectomycorrhizal and arbuscular mycorrhizal fungi, Canadian Journal of Botany. 77, 1833-1841.

Walkley, A., Black, I.A. 1934. An examination of Degtjareff method for determining soil organic matter and a proposed modification of the chromic acid titration method. Soil Science. 37, 29-37. 